TAPROBANICA, ISSN 1800-427X. April, 2012. Vol. 04, No. 01: pp. 20-26, 1 pl.

(C) Taprobanica Private Limited, Jl. Kuricang 18 Gd.9 No.47, Ciputat 15412, Tangerang, Indonesia.

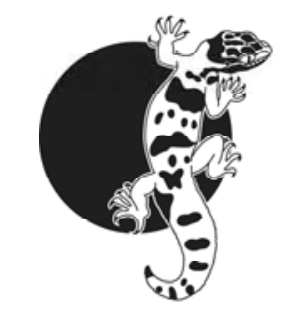

\title{
REPTILE DIVERSITY IN BERALIYA MUKALANA PROPOSED FOREST RESERVE, GALLE DISTRICT, SRI LANKA
}

D. M. S. Suranjan Karunarathna ${ }^{1}$ and A. A. Thasun Amarasinghe ${ }^{2}$

\footnotetext{
${ }^{1}$ Young Zoologists’ Association of Sri Lanka, Department of National Zoological Gardens, Dehiwala, Sri Lanka E-mail: dmsameera@gmail.com

${ }^{2}$ Komunitas Konservasi Alam Tanah Timur, Jl. Kuricang 18 Gd.9 No.47, Ciputat 15412, Tangerang, Indonesia

E-mail: thasun.taprobanica@gmail.com
}

\begin{abstract}
Beraliya Mukalana Proposed Forest Reserve (BMPFR) is a fragmented lowland rainforest patch in Galle District, Sri Lanka. During our two-year survey we recorded a total of 66 species of reptile (28 Lizards, 36 Snakes and 2 Tortoises), which represents $31.4 \%$ of the total Sri Lankan reptile fauna. Thirty-five of the species are endemic to Sri Lanka. Of the recorded 66 species, 1 species is Critically Endangered, 3 are Endangered, 6 are Vulnerable, 14 are Near-threatened and 4 are Data-deficient. This important forest area is threatened by harmful anthropogenic activities such as illegal logging, use of chemicals and land-fill. Environmental conservationists are urged to focus attention on this Wet-zone forest.
\end{abstract}

Key words: Endemics, species richness, threatened, ecology, conservation, wet-zone.

\section{Introduction}

Beraliya Mukalana Proposed Forest Reserve (BMPFR) is an important forest area in Galle District, in the south of Sri Lanka. It is controlled by the Department of Forest Conservation. To date the reptile fauna is unstudied but the results of our survey of the amphibians of the area have been previously published (Karunarathna et al., 2008). Our aim in this study was to focus attention on the reptile species richness and abundance of the area with a view to bringing the various threats these reptiles face to the attention of conservationists and relevant government and non-government organizations.
Study Area: The Beraliya Mukalana Proposed Forest Reserve (BMPFR) area belongs to Alpitiya and Niyagama secretariat divisions of Galle District in Sri Lanka $\left(6^{\circ} 19^{\prime}-6^{\circ} 20^{\prime} \mathrm{N}, 8^{\circ} 10^{\prime}-80^{\circ} 11^{\prime}\right.$ E) (Somasekaran, 1988). The Beraliya Mukalana forest covers 4639 hectares and falls in the southwestern Wet- zone. The area has several small hills, Atuwagala Kanda being the highest at $162 \mathrm{~m}$ and the forest area is 400 feet above sea level (Karunarathna et al., 2008). The forest reserve receives the southwestern monsoon and annual rainfall is about $3660 \mathrm{~mm}$. The average annual temperature is about $28{ }^{\circ} \mathrm{C}$ (Peries, 2003). The 
BMPFR vegetation can be categorized as lowland evergreen rainforest (Gunatillake \& Gunatillake, 1990). The direct distance between the BMPFR and the Sinharaja forest is about $\sim 25 \mathrm{~km}$ and the direct distance from the Kanneliya forest is $\sim 50 \mathrm{~km}$. The area supports a rich network of waterways which includes two waterfalls called "Andahelena Ella" and "Gerandi Ella" (Ella = fall). Among the number of small streams which start from the upper areas, Eliya Dola and Mada Dola (Dola $=$ small stream) are the major tributaries that flow throughout the year.

The study area (BMPFR) has a rich floristic diversity and its composition provides good evidence for identifying it as a primary rainforest (Ashton et al., 1997). Remnants of Dipterocarpus forest occur in valleys and on their lower slopes, with $D$. zeylanicus and $D$. hispidus present in almost pure stands. Secondary forest and scrub occur where the original forest cover has been removed by shifting cultivation and in other places the forest has been replaced by rubber and tea plantations (Karunarathna et al., 2008). Mesua, Doona and Shorea forest, the climax vegetation over most of the reserve, covers the middle and upper slopes of the hills. Garcinia hermonii followed by Xylopia championii invariably dominate the understorey tree stratum, a range of species dominate the subcanopy and Mesua nagassarium usually predominates in the canopy layer. Several invasive plant species such as Lantana camara (Family: Verbenaceae), Tridax procumbens (Family: Asteraceae) and Clidemia hirta (Family: Melastomataceae) have been observed in disturbed areas in the forest margins. There is a monastery (Diwankara-lena temple) and many small caves are also present. Footpaths are found in and around BMPFR.

\section{Materials and Methods}

A total of 28 days ( $\sim 10$ hrs per day) were spent on fieldwork during the two year study period from February 2004 to January 2006. Normally we used visual encounter survey methods but additionally general area surveys, line transects $(100 \mathrm{~m} \times 2 \mathrm{~m})$ and quadrate sampling methods $(10 \mathrm{~m} \times 10 \mathrm{~m})$ were used. Different habitat types (home gardens, scrub jungles, paddy fields, rocky lands, near streams and natural forest) within the BMPFR were all surveyed. Surveys were conducted both day and night and torches (head-lamps) were used at night. All microhabitats such as water bodies, under rocks, logs and decaying vegetation, and trees and bushes up to $8 \mathrm{~m}$, were thoroughly searched for the presence of reptiles. All captured specimens were examined carefully and recorded before being released at their capture site without injury. No specimens were collected, transported or deposited. Road kills and data on animals killed by villagers were also used as additional sources of information.

The species were identified in the field using diagnostic keys given by Deraniyagala (1953, 1955), Das \& de Silva (2005), De Silva (1980), Greer (1991), Whitaker \& Captain (2004) and Wickramasinghe \& Somaweera (2003). After the survey period some specimens were confirmed to species level using Bauer et al. (2010), Batuwita \& Bahir (2005), Batuwita \& Pethiyagoda (2007), Maduwage et al. (2009), Manamendra-Arachchi et al. (2007), Praschag et al. (2011), Rooijen \& Vogel (2009), Somaweera (2006), Somaweera \& Somaweeera (2009), Vogel \& David (2006), Vogel \& Rooijen (2011) and Wickramasinghe et al. (2007). Basic environmental parameters were recorded for locations where specimens were collected. Threat criteria is given according to IUCNSL \& MENR (2007).

\section{Results and Discussion}

During the present two-year survey we were able to record a total of 66 species (Table 1) of reptile representing $36 \quad(n=221)$ species of serpentoid reptiles and $30(n=672)$ species of tetrapod reptiles. These belong to 14 families and 42 genera and include 35 ( $n=456)$ (including unidentified species) endemic reptile species. The endemic and relict genera of snakes (Aspidura, Balanophis and Cercaspis) and of tetrapod reptiles (Lyriocephalus, Ceratophora, Lankascincus and Nessia) were found in BMPFR. Five unidentified species, all of which might be new to science, belonging to the genera Cnemaspis, Ramphotyphlops, Typhlops and Xenochrophis were also recorded during the survey. According to IUCN-SL and MENR-SL (2007) criteria $1(n=3)$ Critically Endangered, $3(n=7)$ Endangered, 6 ( $n=42)$ Vulnerable, 14 ( $n=168)$ Near Threatened and $4(n=23)$ Data deficient species were recorded.

These records show that at least $31.4 \%$ of Sri Lanka's extant reptiles are present in the BMPFR. There is also a significant representation of the country's endemic amphibian species (see Karunarathna et al., 2008). Species such as Ahaetulla pulverulenta, Boiga barnesii, B. forsteni, Chrysopelea ornata, Dendrelaphis schokari, Lycodon striatus, Oligodon calamarius, Balanophis ceylonensis, Bungarus ceylonicus, Rhinophis 
tricoloratus, Ceratophora aspera, Cnemaspis molligodai, Cyrtodactylus cracens, Hemiphyllodatylus typus, Lepidodactylus lugubris, Europis madaraszi and Lankascincus dorsicatenatus were all recorded for the first time in BMPFR. One species of gecko (Cyrtodactylus cracens) and one species of Shield-tail snake (Rhinophis tricoloratus) previously only known from the Sinharaja World Heritage site are now also recorded from BMPFR. More than $40 \%$ of the reptile species were recorded from within the well wooded home gardens that are dominated with native plant species.

The family with the largest number of species is Colubridae (19 sp.), followed by Gekkonidae (12 $s p$.), Scincidae (8 sp.), Agamidae and Natricidae (6 $s p$. each), Viperidae (4 sp.), Elapidae, Typhlophidae and Varanidae (2 sp. each) and Bataguridae, Cylindrophidae, Pythonidae, Trionychidae and Uropeltidae (1 sp. each). We believe the high diversity seen in this Wet-zone forest habitat is mainly due to the isolation of this forest and the availability of a number of microhabitats, including man-modified habitats that are favorable to reptiles. The leading number of endemic species (including unidentified species) is in Colubridae and Gekkonidae (7 $s p$. each), Scincidae (6 sp.), Agamidae and Natricidae (4 sp. each), Viperidae (2 sp.), Cylindrophidae, Elapidae, Trionychidae, Typhlophidae and Uropeltidae (1 sp. each) respectively. In BMPFR the genus Lankascincus (fossorial skinks) are commonly found and 4 out of the 10 species recorded from Sri Lanka occur.

The agamid lizard, Otocryptis wiegmanni is a ground dwelling lizard that is only distributed in shady places near streams or wet areas in the BMPFR. We were able to observe some egg-laying behaviour for this species. Normally they laid 3 to 6 eggs at a single time after digging holes in sandy soil. During one night trip we observed a group (3 to 7 individuals) of the snake Cercaspis carinatus digging the soil (20 mm to $50 \mathrm{~mm}$ deep) and feeding on the eggs of $O$. wiegmanni. This shows that $C$. carinatus can behave as a group during feeding and also that the eggs of $O$. wiegmanni may be a favoured meal.

When considering the 66 species by their primary mode of living there are 29 (43.9\%) terrestrial, 25 (37.9\%) arboreal, 6 (9.1\%) aquatic and 6 (9.1\%) fossorial species. The leading number of terrestrial species is in Colubridae (10 sp.), Scincidae (7 sp.), Viperidae (3 sp.) and Agamidae, Elapidae and Natricidae (2 sp. each). The leading number of arboreal species is in Gekkonidae (11 sp.), followed by Colubridae (9 $s p$.), Agamidae (4 $s p$.) and Viperidae (1 sp.) respectively.

The most uncommon tetrapod reptile species are Lepidodactylus lugubris $(n=1)$, followed by Geckoella triedrus and Hemiphyllodatylus typus $(n=2$ each); the most uncommon snakes are Ahaetulla pulverulenta and Typhlops cf. lankaensis ( $n=1$ each), followed by Amphiesma stolata, Balanophis ceylonensis, Boiga forsteni, Dendrelaphis bifrenalis, Lycodon striatus and Python molurus ( $n=2$ each). Snakes were well represented in home gardens with some species hiding in the shaded and cool roofs of some village houses. At night time all snakes moved from the houses to the forest areas to forage. Most of the fossorial and semi-fossorial species of snake were recorded after the rainy season, particularly in the well-shaded canopy covered areas. Among serpentoid reptiles Aheatulla nasuta, Cercaspis carinatus, Hypnale hypnale, Lycodon aulicus, Ptyas mucosa and Xenocrophis cf. piscator are the most common and widespread species. In terms of tetrapod reptiles Calotes calotes, C. versicolor, Cnemaspis molligodai, C. silvula, Eutropis carinata, E. macularia, Gehyra mutilata, Hemidactylus parvimaculatus, $H$. frenatus, Lankascincus fallax, L. gansi, L. greeri and Otocryptis wiegmanni were the most common and widespread.

In terms of the species abundance in each habitat type, the highest species abundance occurred in Natural forests $30.6 \%(n=273)$, followed by Home gardens $26.4 \%(n=236)$, Near streams $17.8 \%$ $(n=159)$, Rocky land areas $12.2 \%(n=109)$ and the lowest species abundance occurred in Paddy fields $7.1 \%(n=63)$ and Scrub jungles $5.9 \%(n=53)$. The high species abundance in the Natural forest habitat may be due to the high amount of leaf litter, shaded forest patches, micro-habitats (e.g., tree holes, caves, tree bark, rock boulders, crevices, water holes, decaying logs, loose soil, and other small niches), favorable climatic conditions and also the abundant availability of food resources such as small vertebrates and invertebrates (e.g. frogs, geckos, skinks, lizards, small mammals, small birds, animal eggs, earthworms, ground insects etc.) on which to feed. The highest number of endemic species was found in Natural forest (29) followed by Near streams (24), Rocky land areas (15) and Home gardens (12). Scrub jungles (7) and Paddy fields (5) showed the lowest number of endemic species. 


\section{Threats and conservation concern}

Several areas of the Beraliya Forest have been cleared for tea and rubber cultivation. Other areas have been adversely impacted by illegal logging. Every day the disturbances in this forest are increasing with many local visitors coming on picnics or trips. These people sometimes leave glass bottles, polythene bags and other assorted rubbish inside the forest. Many streams and watercourses in the forest have become contaminated with broken glass, polythene, clothes, garbage and soap. This forest area is also a base for local illegal alcohol producers. They utilise many streams to produce their alcohol and discard all the remaining poisonous residues of their products into the streams. These streams are also contaminated with the many pesticides and chemicals used for agriculture practices like paddy cultivation. Riverside vegetation has been cut back around the communities and invasive species have replaced natural habitats.

Many wet areas have been in-filled by the local people who have made many small road networks and because of this many habitats used by tadpoles have been destroyed. Due to mythical beliefs many people kill all the snakes they meet. In addition the villagers kill land monitors and other mammals for meat and water monitors for oil. Many of the boundary markers for the forest erected by the Forestry Department have been removed and inside the forest we have observed domestic cats and dogs chasing wild animals. Road kills are another major threat around this forest patch due to its high fragmentation.

Even though this forest patch is controlled by the Department of Forestry we have never seen any of their officials in or around the forest. There is a monastery inside the forest and the only pristine forest patch remaining survives around the monastery.

\section{Acknowledgements}

The authors would like to express their sincere thanks to N. Karunarathna, T. Abewardena, A. Kumarasinghe, P. Silva, T. Peries, C. Soysa, R. Sirimanna, D. Jayamanna, M. Madawala and A. Udayakumara from the YZA for their help in fieldwork. Also Mendis Wickramasinghe (HFS), Kelum Manamendra-Arachchi (WHT) and an anonymous reviewer for valuable comments. Dushantha Kandambi is acknowledged for photographs and thanks are due to many villagers for providing accommodation. Finally, the first author thanks the Department of Forestry and the
Department of Wildlife Conservation of Sri Lanka for permissions (FRC/7 \& WL/3/2/1/4/10) to undertake field work.

\section{Literature Cited}

Ashton, M., C. V. S Gunatileke, N. De Zoysa, M. D. Dassanayake, N. Gunatileke and S. Wijesundara, 1997. A field guide to the common trees and shrubs of Sri Lanka. Wildlife Heritage Trust of Sri Lanka: 455.

Batuwita, S. and M. M. Bahir, 2005. Description of five new species of Cyrtodactylus (Reptilia: Gekkonidae) from Sri Lanka. In: Yeo, D. C. J., P. K. L. Ng and R. Pethiyagoda (eds.). Contributions to biodiversity exploration and research in Sri Lanka. The Raffles Bulletin of Zoology, Supplement No. 12: 351-380.

Batuwita, S. and R. Pethiyagoda, 2007. Description of a new species of Sri Lankan litter skink (Squamata: Scincidae: Lankascincus). Ceylon Journal of Science (Biological Science), 36 (2): 80-87.

Bauer, A., T. R. Jackman, E. Greenbaum, A. de Silva, V. B. Giri and I. Das, 2010. Molecular evidence for the taxonomic status of Hemidactylus brookii group taxa (Squamata: Gekkonidae). Herpetological Journal, 20: 129-138.

Das, I. and A. de Silva, 2005. Photographic guide to the Snakes and other Reptiles of Sri Lanka. New Holland Publishers: 144.

Deraniyagala, P. E. P., 1953. A Colored Atlas of some vertebrates from Ceylon, Tetrapod Reptilia. National Museums of Sri Lanka, Colombo, Vol. 02: 101.

Deraniyagala, P. E. P., 1955. A Colored Atlas of Some Vertebrates from Ceylon, Serpentoid Reptilia. National Museums of Sri Lanka, Colombo, Vol. 03: 121.

De Silva, P. H. D. H., 1980. Snake Fauna of Sri Lanka, with special reference to skull, dentition and venom in snakes. National Museums of Sri Lanka, Colombo: 480.

Greer, A. E., 1991. Lankascincus, a new genus of Scincid lizards from Sri Lanka with descriptions of three new species. Journal of Herpetology, 25 (1): 5964.

Gunatilleke, I. A. U. N. and C. V. S. Gunatilleke, 1990. Distribution of Floristic Richness and its Conservation in Sri Lanka. Conservation Biology, 4 (1): 21-31.

IUCNSL and MENR, 2007. The 2007 Red List of Threatened Fauna and Flora of Sri Lanka. Colombo, IUCN Sri Lanka: 148. 
Karunarathna, D. M. S. S., U. T. I. Abeywardena, A. A. T. Amarasinghe, D. G. R. Sirimanna and M. D. C. Asela, 2008. Amphibian faunal diversity of Beraliya Mukalana Proposed Forest Reserve. Tigerpaper, 35 (2): 12-16.

Maduwage, K., A. Silva, K. Manamendra-Arachchi and R. Pethiyagoda, 2009. A taxonomic revision of the South Asian hump-nosed pit vipers (Squamata: Viperidae: Hypnale). Zootaxa, 2232: 1-28.

Manamendra-Arachchi, K., S. Batuwita and R. Pethiyagoda, 2007. A taxonomical revision of the Sri Lankan day-geckos (Reptilia: Gekkonidae: Cnemaspis), with description of new species from Sri Lanka and India. Zeylanica, 7 (1): 9-122.

Peries, H. T. A. P., 2003. The Beraliya Mukalana Forest in Galle district. Report of the Young Zoologists’ Association of Sri Lanka: 14.

Praschag, P., H. Stuckas, M. Packert, J. Maran and U. Fritz, 2011. Mitochondrial DNA sequences suggest a revised taxonomy of Asian flapshell turtles (Lissemys SMITH, 1931) and the validity of previously unrecognized taxa (Testudines: Trionychidae). Vertebrate Zoology, 61 (1): 147-160.

Rooijen, J. V. and G. Vogel, 2009. A multivariate investigation into the population systematics of Dendrelaphis tristis (Daudin, 1803) and Dendrelaphis schokari (Kuhl, 1820): revalidation of Dendrophis chairecacos Boie, 1827 (Serpentes: Colubridae). Herpetological Journal, 19: 193-200.
Somasekaran, T., 1988. The National Atlas of Sri Lanka: Surveys Department Sri Lanka: 152.

Somaweera, R. 2006. Snakes of Sri Lanka (Sinhala text). Wildlife Heritage Trust of Sri Lanka: 297.

Somaweera, R. and N. Somaweera, 2009. Lizards of Sri Lanka: A colour guide with field keys. Edition Chimaira, Frankfurt am Main, Germany: 303.

Vogel, G. and P. David, 2006. On the taxonomy of the Xenochrophis piscator complex (Serpentes, Natricidae), In: Herpetologia Bonnensis II: Proceedings of the $13^{\text {th }}$ Congress of the Societas Europaea Herpetologica, Vences, M., J. Köhler, T. Ziegler \& W. Böhme (eds.): 241-246.

Vogel, G, and J. V. Rooijen, 2011. A new species of Dendrelaphis (Serpentes: Colubridae) from the Western Ghats - India. Taprobanica, 3 (2): 77-86.

Wickramasinghe, L. J. M., R. Rodrigo, N. Dayawansa and U. L. D. Jayantha, 2007. Two new species of Lankascincus (Squamata: Scincidae) from Sripada Sanctuary (Peak Wilderness), in Sri Lanka. Zootaxa, 1612: 1-24.

Wickramasinghe, L. J. M. and R. K. Somaweera, 2003. Distribution and Current Status of the Endemic Geckos of Sri Lanka. Gekko, 3 (1): 2-13.

Whitaker, R. and A. Captain, 2004. Snakes of India: The field guide. Draco Publication Limited. India: 486.

Table 1: Reptiles checklist of the BMPFR (Abbreviation: E, Endemic species; CR, Critically endangered; EN, Endangered; VU, Vulnerable; NT, Near threatened; DD, Data deficient; TOC, Total Individual count and REA, relative abundance).

\begin{tabular}{|c|c|c|c|}
\hline Scientific name and families & Common name and status & TOC & REA \% \\
\hline \multicolumn{4}{|l|}{ Family Pythonidae } \\
\hline Python molurus & Indian python & 2 & 0.22 \\
\hline \multicolumn{4}{|l|}{ Family Colubridae } \\
\hline Ahaetulla nasuta & Green vine Snake & 16 & 1.79 \\
\hline Ahaetulla pulverulenta & Brown vine Snake ${ }^{\mathrm{NT}}$ & 1 & 0.11 \\
\hline Boiga barnesii & Barnes's cat Snake ${ }^{\text {E/NT }}$ & 3 & 0.34 \\
\hline Boiga ceylonensis & Sri Lankan cat Snake & 3 & 0.34 \\
\hline Boiga forsteni & Forsten's cat Snake & 2 & 0.22 \\
\hline Cercaspis carinatus & Sri Lanka wolf Snake ${ }^{\mathbf{E} / \mathbf{V U}}$ & 21 & 2.35 \\
\hline Chrysopelea ornata & Ornate flying Snake ${ }^{\mathrm{NT}}$ & 3 & 0.34 \\
\hline Coelognathus helena & Trinket Snake & 4 & 0.45 \\
\hline
\end{tabular}




\begin{tabular}{|c|c|c|c|c|}
\hline \multicolumn{2}{|c|}{ Scientific name and families } & \multirow{2}{*}{$\begin{array}{l}\text { Common name and status } \\
\text { Gunther's bronze Back }^{\text {vu }}\end{array}$} & \multirow{2}{*}{$\frac{\text { TOC }}{4}$} & \multirow{2}{*}{$\begin{array}{r}\text { REA \% } \\
0.45\end{array}$} \\
\hline 10 & Dendrelaphis caudolineolatus & & & \\
\hline 11 & Dendrelaphis bifrenalis & Boulenger's bronze Back ${ }^{\mathrm{E}}$ & 2 & 0.22 \\
\hline 12 & Dendrelaphis schokari & Common bronze Back ${ }^{\mathbf{E}}$ & 9 & 1.01 \\
\hline 13 & Lycodon aulicus & Common wolf Snake & 10 & 1.12 \\
\hline 14 & Lycodon osmanhilli & Flowery wolf Snake ${ }^{\mathrm{E}}$ & 5 & 0.56 \\
\hline 15 & Lycodon striatus & Barred wolf Snake & 2 & 0.22 \\
\hline 16 & Oligodon arnensis & Common kukri Snake & 8 & 0.90 \\
\hline 17 & Oligodon sublineatus & Dumeril's kukri Snake ${ }^{\mathrm{E}}$ & 4 & 0.45 \\
\hline 18 & Oligodon calamarius & Templeton’s kukri Snake E /vu & 3 & 0.34 \\
\hline 19 & Ptyas mucosa & Common rat Snake & 17 & 1.90 \\
\hline 20 & Sibynophis subpunctatus & Jordan’s Poligodont & 6 & 0.67 \\
\hline \multicolumn{5}{|c|}{ Family Cylindrophidae } \\
\hline 21 & Cylindrophis maculatus & Sri Lanka pipe Snake ${ }^{\mathrm{E} / \mathrm{NT}}$ & 5 & 0.56 \\
\hline \multicolumn{5}{|c|}{ Family Natricidae } \\
\hline 22 & Amphiesma stolatum & Buff striped Keelback & 2 & 0.22 \\
\hline 23 & Aspidura guentheri & Ferguson's Roughside ${ }^{\mathrm{E} / \mathrm{NT}}$ & 4 & 0.45 \\
\hline 24 & Atretium schistosum & Olive Keelback & 6 & 0.67 \\
\hline 25 & Balanophis ceylonensis & Blossom Krait $^{\text {E / VU }}$ & 2 & 0.22 \\
\hline 26 & Xenochrophis asperrimus & Sri Lanka Checkered Keelback ${ }^{\mathrm{E}}$ & 11 & 1.23 \\
\hline 27 & Xenochrophis cf. piscator & Common checkered Keelback ${ }^{\mathbf{E}}$ & 16 & 1.79 \\
\hline \multicolumn{5}{|c|}{ Family Elapidae } \\
\hline 28 & Bungarus ceylonicus & Ceylon Krait ${ }^{\mathrm{E} / \mathrm{NT}}$ & 3 & 0.34 \\
\hline 29 & Naja naja & Common Cobra & 5 & 0.56 \\
\hline \multicolumn{5}{|c|}{ Family Typhlophidae } \\
\hline 30 & Ramphotyphlops cf. braminus & Blind Snake sp. ${ }^{\text {DD }}$ & 7 & 0.78 \\
\hline 31 & Typhlops cf. lankaensis & Blind Snake sp. ${ }^{\mathbf{E} / \mathbf{D D}}$ & 1 & 0.11 \\
\hline \multicolumn{5}{|c|}{ Family Uropeltidae } \\
\hline 32 & Rhinophis tricoloratus & Deraniyagala’s Shieldtail E / DD & 4 & 0.45 \\
\hline \multicolumn{5}{|c|}{ Family Viperidae } \\
\hline 33 & Daboia russelii & Russell's Viper & 3 & 0.34 \\
\hline 34 & Hypnale hypnale & Merrem’s hump-nosed Viper & 16 & 1.79 \\
\hline 35 & Hypnale zara & Lowland hump-nosed Viper ${ }^{\mathbf{E}}$ & 7 & 0.78 \\
\hline 36 & Trimeresurus trigonocephalus & Green pit Viper $^{\mathbf{E}}$ & 4 & 0.45 \\
\hline \multicolumn{5}{|c|}{ Family Bataguridae } \\
\hline 37 & Melanochelys trijuga & Black Turtle $^{\text {NT }}$ & 15 & 1.68 \\
\hline \multicolumn{5}{|c|}{ Family Trionychidae } \\
\hline 38 & Lissemys ceylonensis & Soft shell Turtle ${ }^{\mathrm{E} / \mathrm{Vu}}$ & 8 & 0.90 \\
\hline \multicolumn{5}{|c|}{ Family Agamidae } \\
\hline 39 & Calotes calotes & Green garden Lizard & 18 & 2.02 \\
\hline 40 & Calotes liolepis & Whistling Lizard $\mathbf{E}$ / VU & 4 & 0.45 \\
\hline 41 & Calotes versicolor & Common garden Lizard & 25 & 2.80 \\
\hline 42 & Ceratophora aspera & Rough horn Lizard ${ }^{\text {E/EN }}$ & 4 & 0.45 \\
\hline 43 & Lyriocephalus scutatus & Lyre head Lizard $^{\mathrm{E}}$ / NT & 4 & 0.45 \\
\hline 44 & Otocryptis wiegmanni & Sri Lankan kangaroo Lizard ${ }^{\text {E /NT }}$ & 28 & 3.14 \\
\hline
\end{tabular}




\begin{tabular}{|c|c|c|c|c|}
\hline \multicolumn{2}{|c|}{ Scientific name and families } & Common name and status & TOC & REA \% \\
\hline \multicolumn{5}{|c|}{ Family Gekkonidae } \\
\hline 45 & Cnemaspis molligodai & Molligoda's day gecko ${ }^{\mathrm{E} / \mathrm{NT}}$ & 49 & 5.49 \\
\hline 46 & Cnemaspis silvula & Forest day gecko $^{\mathrm{E}}$ & 32 & 3.58 \\
\hline 47 & Cnemaspis cf. silvula & Day gecko sp. ${ }^{\mathrm{E} ?}$ & 44 & 4.93 \\
\hline 48 & Cnemaspis cf. tropidogaster & Day gecko sp. ${ }^{\mathrm{E} ?}$ & 36 & 4.03 \\
\hline 49 & Cyrtodactylus cracens & Narrow headed forest Gecko ${ }^{\mathrm{E} / \mathrm{CR}}$ & 3 & 0.34 \\
\hline 50 & Geckoella triedrus & Spotted bowfinger Gecko E / NT & 2 & 0.22 \\
\hline 51 & Gehyra mutilata & Four claw Gecko & 46 & 5.15 \\
\hline 52 & Hemidactylus parvimaculatus & Spotted house Gecko & 59 & 6.61 \\
\hline 53 & Hemidactylus depressus & Kandyan Gecko $^{\mathrm{E}}$ & 14 & 1.57 \\
\hline 54 & Hemidactylus frenatus & Common house Gecko & 29 & 3.25 \\
\hline 55 & Hemiphyllodactylus typus & Slender Gecko ${ }^{\text {EN }}$ & 2 & 0.22 \\
\hline 56 & Lepidodactylus lugubris & Scaly finger Gecko EN & 1 & 0.11 \\
\hline \multicolumn{5}{|c|}{ Family Scincidae } \\
\hline 57 & Eutropis carinata & Common Skink & 48 & 5.38 \\
\hline 58 & Europis macularia & Bronze green little Skink & 58 & 6.49 \\
\hline 59 & Europis madaraszi & Spotted Skink ${ }^{\mathrm{E} / \mathrm{NT}}$ & 16 & 1.79 \\
\hline 60 & Lankascincus fallax & Common lanka Skink $^{\mathrm{E}}$ & 37 & 4.14 \\
\hline 61 & Lankascincus dorsicatenatus & Catenated lanka Skink ${ }^{\mathbf{E} / \mathbf{D D}}$ & 11 & 1.23 \\
\hline 62 & Lankascincus gansi & Gans's lanka Skink E /NT & 26 & 2.91 \\
\hline 63 & Lankascincus greeri & Greer's lanka Skink $^{\mathrm{E}}$ & 30 & 3.36 \\
\hline 64 & Nessia burtonii & Three toe snake Skink ${ }^{\mathrm{E} / \mathrm{NT}}$ & 4 & 0.45 \\
\hline \multicolumn{5}{|c|}{ Family Varanidae } \\
\hline 65 & Varanus bengalensis & Land Monitor & 11 & 1.23 \\
\hline 66 & Varanus salvator & Water Monitor & 8 & 0.90 \\
\hline
\end{tabular}




\section{Plate 01}

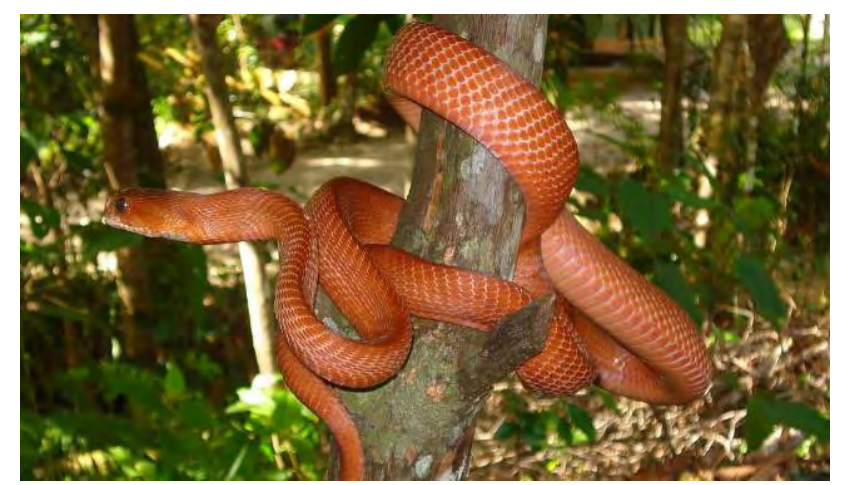

Fig. 1: Boiga forsteni

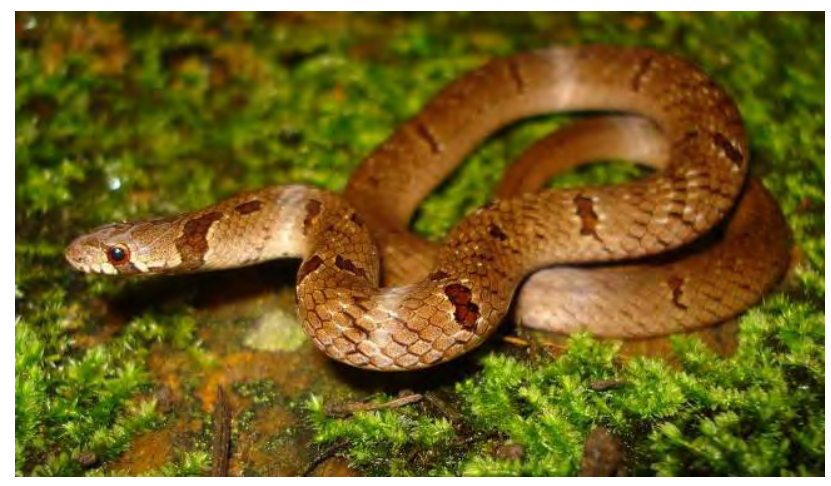

Fig. 3: Oligodon sublineatus

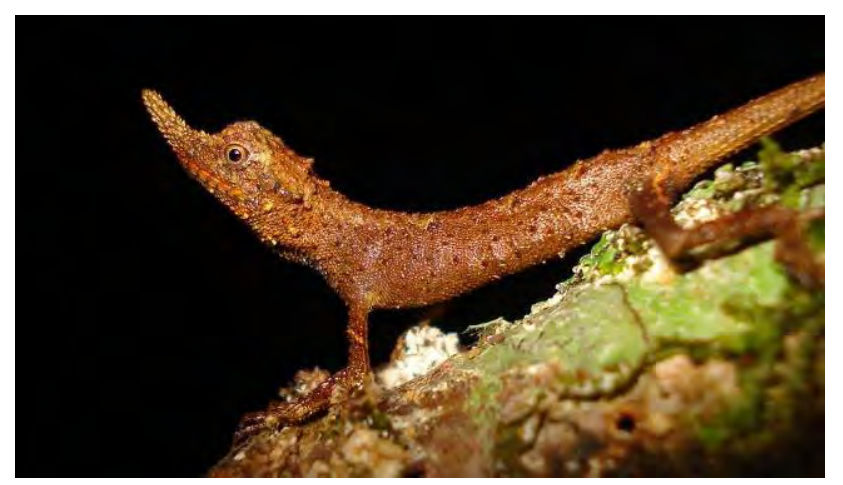

Fig 5: Ceratophora aspera

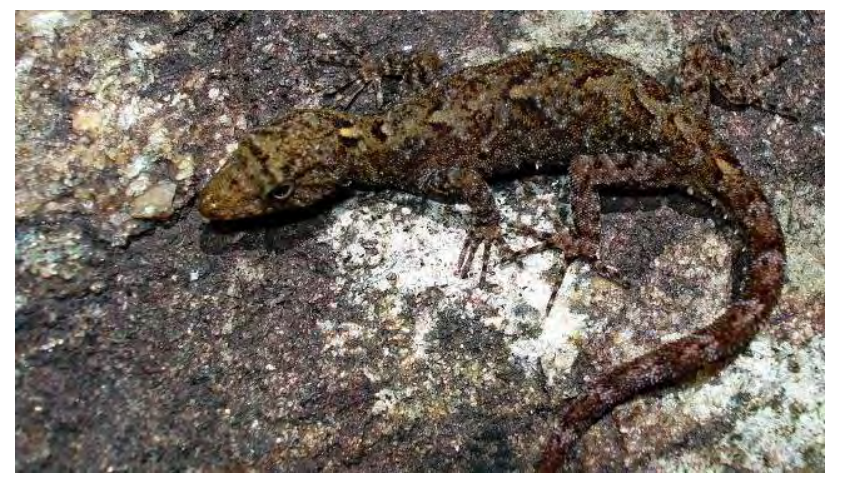

Fig. 7: Cnemaspis silvula

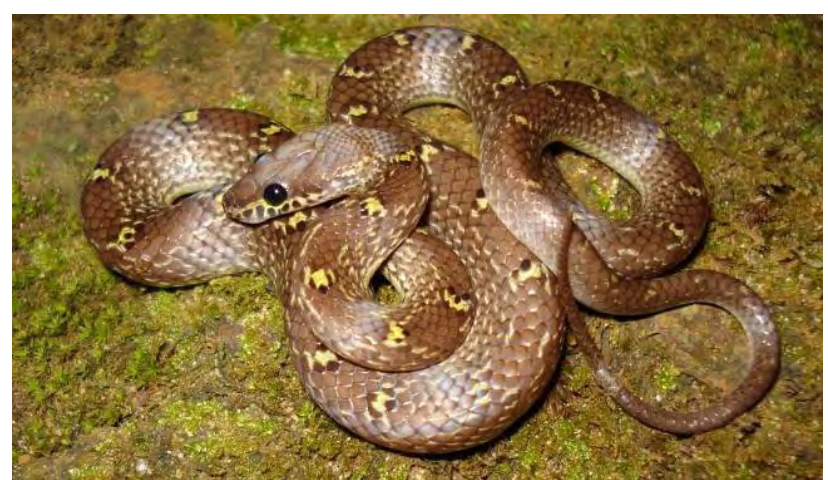

Fig. 2: Lycodon osmanhilli

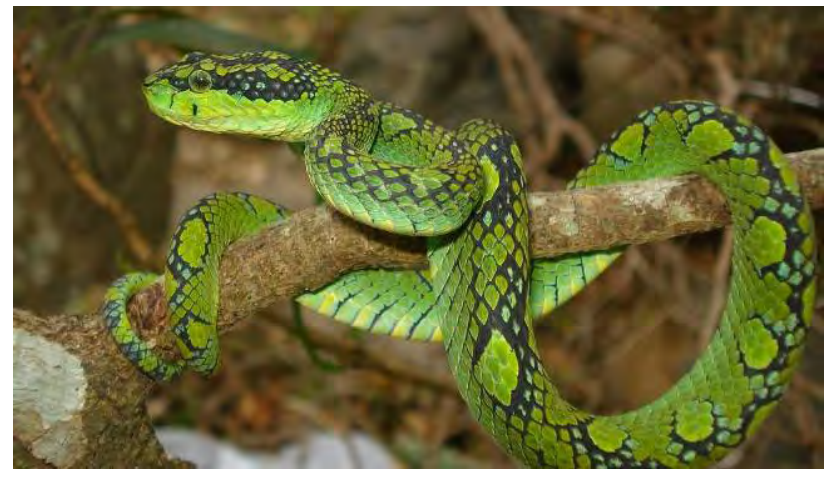

Fig. 4: Trimeresurus trigonocephalus

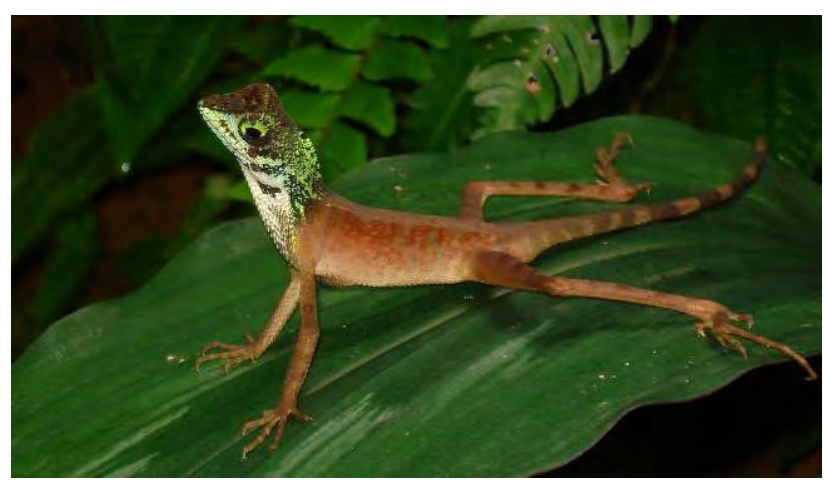

Fig. 6: Otocryptis wiegmanni

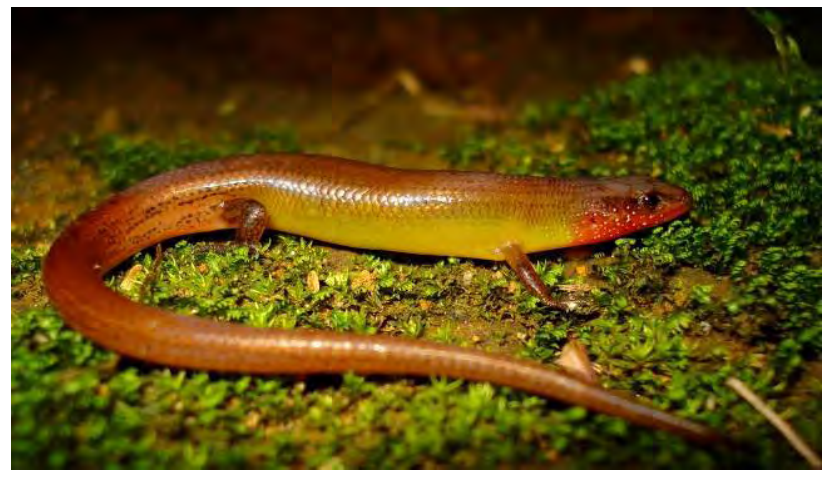

Fig. 8: Lankascincus fallax 